УДК 378.316.621(092)

DOI:

Тетяна Мартинюк, доктор мистеитвознавства, професор, завідувач кафедри мистещьких дисииплін і методик навчання ДВНЗ "Університет Григорія Сковороди в Переяславі"

\title{
АКТУАЛЬНІ ПРОБЛЕМИ ПРОФЕСІЙНОЇ ОСВІТИ У НАУКОВОМУ ПРОСТОРІ ПРОФЕСОРА ТАНІТИ ЛЮРІНӦ̈
}

У статті висвітлено актуальні проблеми професійної освіти у науковому просторі професора T. Люріної. Розкрито авторську позицію щчодо краєвознавства та екологічної культури в початкової освіті. Виявлено, шьо ефективному результату проиесу розвитку і формування екологічної культури у молодших школярів сприяє комплекс педагогічних умов: створення еколого-виховного середовища у закладі вищої освіти; впровадження нових освітніх технологій у позааудиторній екологічній діяльності студентів; удосконалення чинних та розробка низки спецкурсів з широкого спектру проблем екологічного виховання.

Ключові слова: екологічна культура; краєвознавство; початкова освіта; Т. Люріна.

Jim. 5.

Tetyana Martynyuk, Doctor of Sciences (Art History), Professor, Head of the Art Disciplines and Teaching Methods Department SHEI "Hryhoriy Skovoroda University in Pereyaslav"

\section{CURRENT PROBLEMS OF VOCATIONAL EDUCATION IN THE SCIENTIFIC SPACE OF PROFESSOR TANITA LYURINA}

In the article it is considered the topical problems of vocational education in the scientific space of Professor Tanita Lyurina. It is outlined that the educational process of secondary school plays a major role in reforming of the vocational education of higher education institutions in Ukraine. The theoretical and practical aspects of the modern pedagogical and art studies are revealed. It is stated that the urgency of the problem of vocational pedagogy increases due to the practical training of future professionals, which affects the students' spiritual world.

The scientific works of ProfessorT.Lyurina on the issues of this phenomenon are considered, in which the role of local history, the problems of ecological culture, which contribute to the peculiarities of preservation and revival of national traditons, are revealed. The emphasis is placed on the importance of modern researches use in this area.

The analysis of modern researches of the specified phenomenon gives the bases to assert about implementation of adjustments to the structural-categorical device which provide successful practical realization of the maintenance of educational process. In this regard, the certain conditions of the development and formation process of the junior schoolchildren's ecological culture are outlined. The emphasis is placed on the need to use in the educational process of primary education new forms and methods that involve the acquisition of professional knowledge, skills and abilities in environmental culture and form a unique spiritual and creative personality of the future specialist.

Summarizing the mentioned about, it should be noted that Professor T. Lyurina in the scientific works offers a new concept in the scientific space of the education system, based on the priority of professional thinking, creativity of participants of the educational process, justifies the need to review sources of knowledge and pedagogical experience and refinement of professional system on the fundamentally new basis.

Keywords: an ecological culture; local history; primary education; T. Lyurina.

П остановка проблеми. Сучасні умови вищої педагогічної освіти в Україні передбачають впровадження нових освітніх стандартів. Функціонування системи пропедевтичних знань про людину та культурно-історичні особливості того чи того регіону покликане сприяти становленню цілісних світоглядних уявлень юних громадян нашої країни про людину і суспільство. Така спрямованість розвитку професійної освіти окреслює важливі пріоритети педагогіки вищої школи. Серед них: становлення широкого гуманітарного світогляду майбутніх вчителів початкових класів, осягнення феномена людини в багатогранності її проявів, системи поглядів про культурно-історичні відмінності окремих регіонів України. Виховання екологічної культури, краєвознавства майбутнього фахівця передбачає формування педагогічного мислення, яке базується на системі теоретичних знань 3 педагогіки і психології, виявлясться у здатності використовувати ці знання, оперувати ними у практичній діяльності.

Аналіз останніх досліджень і публікацій. Проблеми шкільного краєзнавства отримали 


\section{АКТУАЛЬНІ ПРОБЛЕМИПРОФЕСІЙНОӤ ОСВІТИ У НАУКОВОМУ ПРОСТОРІПРОФЕСОРА ТАНІТИЛЮРІНОЇ}

обгрунтування у низці наукових праць учених: О. Баркова, А. Даринського, Я. Жупанського, В. Корнєєва, М. Костриці, М. Крачила, В. Круля, В. Обозного, І. Пруса, К. Строєва та ін. Проблема морального виховання особистості розглядалася А. Запорожцем, К. Платоновим, М. Стельмаховичем, В. Сухомлинським, Н. Волковою, О. Рудницькою, Н. Мирончук, К. Журбою та ін. Значний внесок у розв'язання проблем екологічної освіти в загальноосвітній школі зробили Г. Волошина, Л. Іщенко, І. Костицька, С. Карпеєва, Д. Мельник. Питання екологічної підготовки студентів вищих та середніх спеціальних закладів освіти, формування в них екологічної культури та виховання розглянуті у студіях М. Бойчевої, О. Дорошко, Е. Кучиної, Л. Лук’янової.

Отже, метою статті $\epsilon$ висвітлення актуальних проблем професійної освіти в науковому просторі професора Таніти Іванівни Люріної.

Виклад основного матеріалу. Активізація людського фактора, створення необхідних умов для більш повного розкриття творчого потенціалу кожної людини є однією з визначальних ознак сучасної освітньої системи. У наукових працях українських вчених наголошується на винятковому значенні дитинства у формуванні особистості та необхідності оновлення й удосконалення системи дошкільного виховання. Однією з рис, яка окреслює змістову наповненість сучасної освітньої системи, є формування рекреаційної екологічної культури особистості. Становлення ii фундаментальних засад відбувається з раннього шкільного віку. Саме тому виняткової значущості набуває введення до освітнього процесу підготовки вчителя початкових класів краєзнавчого елемента.

Пріоритет розвитку вищої школи - підготовка вчителів початкових класів. Віддзеркаленням цієі тенденції є створення і функціонування у системі початкової освіти низки інноваційних курсів, таких як “Народознавство”, “Я і Україна”, “Люби і знай свій рідний край та інші”.

Важливе завдання подальшого наукового пошуку становить більш глибоке висвітлення питань, пов'язаних 3 підготовкою вчителів до організації краєзнавчої роботи зі школярами. 3 цього приводу надзвичайною змістовною наповненістю вирізняється навчальнометодичний посібник Т. Люріної, В. Молодиченка i C. Танани “Організація краєзнавчої роботи в початковій школі”, призначений для самостійної роботи майбутніх викладачів. Автори дослідження зазначають, що у добу Київської Русі формується історіографія. Найбільш повно вона представлена літописами - основними джерелами літератури та історії Княжої України. Українське літописання почалося у Києві при кафедрі св. Софії у перші десятиліття XI ст. Згодом літописи почали створювати у Києво-Печерському монастирі.

Зміст навчально-методичного посібника вирізняється широтою літературної та історичної думки й погляду, критичним осмисленням різних джерел, зокрема українських літописців. Загальновідомо, що хронологічний запис поточних подій здійснювався здебільшого ченцями у монастирях. В літописних зводах їх автори ставлять науково-історичні цілі, пов'язані 3 тогочасним політичним і церковним життям. Вершинне досягнення княжої доби - “Повість врем'яних літ" - найстаріша історія української землі. Цей твір сповнений глибокого патріотичного почуття і містить велику кількість політичних, географічних та етнографічних відомостей. Він став підгрунтям для створення у різних містах України низки пізніших літописів.

У зв'язку з цим професор Т. Люріна зазаначає, що “ЗЗерігаючи історичну пам’ять, демократичногуманістичні традиції, українознавство стає міцною підвалиною формування української національної ідеї та концепції державотворення" $[1,134]$. Наголошується на тому, що “Філософській - гуманістичний, етико-естетичний - підхід і зумовив найголовнішіосвітні засадилітературознавства" $[1,134]$. Тобто, формування характерів людей і поколінь - так можна відзначити культурологічне кредо української освітньої системи. Завдання педагогів полягає у тому, щоб допомагати людині в пізнанні самої себе, навколишнього світу, а також у реалізації свого творчого життєвого потенціалу.

У такому контексті, на думку Т. Люріної, література набуває виняткового значення, даючи змогу більш глибоко пізнати сутність філософських категорій, дотичних до таких явищ, як національний світогляд, ментальність тощо, характеристики яких важко піддаються науковим формуванням. "Українознавче осмислення літератури сприяє більш глибокому розумінню проблеми етнічності, національної ідентичності, культурної універсальності, культурної гібридності та культурної відмінності, проблеми мови, історії” $[1,135]$. Так, Т. Люріна наголошує на тому, що у філософській спадщині Г. Сковороди вперше обгрунтовано ідею про те, що досконалість світу віддзеркалює процес розвитку самої людини і рівень їі культури. На погляд філософа П. Юркевича, сприйняття людиною навколишнього світу і світу суспільного буття відбувається у формі своєрідного синтезу чуттєвого переживання, ядром якого є людське серце. У своєму 


\section{АКТУАЛЬНІ ПРОБЛЕМИПРОФЕСІЙНОӤ ОСВІТИ У НАУКОВОМУ ПРОСТОРІПРОФЕСОРА ТАНІТИЛЮРІНОЇ}

дослідженні науковець здійснює аналіз літературного доробку Олександра Довженка, в якому з винятковою повнотою розкривається ментальність українців. Гуманістичні ідеали, внутрішній світ людини стають об'єктом глибокого осмислення у творчості визначних письменників. Увагу автора привертає літературний доробок Юрія Мушкетика, в якому виразно постає проблема: людина, особистість і система.

Отже, професор Т. Люріна констатує неабияку значущість виховного потенціалу української літератури у викладанні українознавства з огляду на те що “... вона $є$ конгломератом світоглядних, духовно моральних і суспільно-естетичних поглядів народу. Проникнути в глибини світоглядних уявлень про навколишній світ та місце людини в ньому можливо завдяки вивченню літературної творчості крізь призму українознавчого контексту" [1, 138-139].

Наукові праці професора Т. Люріної цілісно охоплюють низку актуальних проблем функціонування сучасної початкової освіти. Однією із таких розвідок є $\dddot{1}$ стаття “Організаційно-педагогічні основи адаптивної системи навчання молодших школярів” [2]. Зміст наукової праці віддзеркалює новітню парадигму розвитку загальноосвітньої школи, сутність якої полягає у формуванні цілісної системи універсальних знань і навичок, а також набуття досвіду самостійної діяльності та відчуття особистої відповідальності школярів. Т. Люріна обгрунтовує тезу про те, що якість засвоєння й усвідомлення знань буде зростати тоді, коли модель розв'язання навчально-пізнавальних завдань буде мати своїм підгрунтям особистісноорієнтований підхід. Його важливою складовою $\epsilon$ адаптація до індивідуальних механізмів засвоєння, що поєднують різні структури інтелектуальних процесів.

Науковець сучасності Т. Люріна висловлює думку про те, що зміст навчання розкривається перед особистістю з найбільшою повнотою тоді, коли постає у формі навчально-пізнавального завдання. Адаптивна система навчання тлумачиться автором праці як педагогічне явище, що поєднує найкращі риси програмового навчання 3 можливістю його подальшого вдосконалення і розвитку. У статті пропонуються різні методологічні підходи до організації освітнього процесу. Сутність асоціативного підходу полягає в утворенні системи асоціацій. Використання теорії змістовних узагальнень - це важливий чинник формування цілісної картинки світу в свідомості особистості.
У науковій праці представлено модель особистісно-орієнтованого підходу, структурними елементами якого виступає концепція логічних рівнів; 1) упровадження сучасних інформаційних технологій; 2) теорія змістовних узагальнень; 3) теорія проблемного навчання; теорія асоціацій; спрямованість на самостійну роботу; 4) організація системи навчання, яка віддзеркалює індивідуальні риси особистості учнів тощо.

Нагадаємо, що налагодження органічної взаємодії суспільства і природи шляхом підвищення екологічної культури громадян $€$ однією з найбільш актуальних в цивілізованих країнах. Освітня місія вищої освіти в сучасному українському суспільстві полягає у формуванні такої особистості, для якої цінність природи і суспільства стає важливою складовою гуманістичного світогляду. В сучасному світі екологічна освіта визначається як актуальна проблема. Важливим вектором фахової підготовки майбутніх вчителів $є$ спрямованість на формування екологічної культури школярів. Цей процес - безперервний і цілісний, охоплює низку структурних елементів. Важливим його аспектом $\epsilon$ становлення у студентської молоді інтересу до фундаментальних проблем взаємодії суспільства і природи.

У науковому дослідженні професора Т. Люріної "Підготовка майбутніх учителів початкової школи до формування в учнів екологічної культури” [4] стверджується, що теорія і практика екологічної освіти має своїм підгрунтям загальні педагогічні принципи освітнього процесу, а також специфічні принципи розвитку відповідального ставлення до природи. Початковий етап в екологічній шкільній освіті визначається у статті як особливо відповідальний. Контакти дитини з природою мають надзвичайний вплив на їі інтелектуальну й емоційну сферу. "Головною метою екологічного виховання $є$ формування екологічної культури, яка повинна включати в себе екологічний імператив, систему екологічних цінностей та екологічну відповідальність" [4, 61].

Отже, у науковій праці професора Т. Люріної визначено основні пріоритети педагогічної освіти у процесі розвитку і формування у молодших школярів екологічної культури. Для успішності досягнення мети можна окреслити педагогічні умови: 1) створення еколого-виховного середовища узакладі вищої освіти; 2) впровадження нових освітніх технологій в позааудиторній екологічній діяльності студентів; 3) удосконалення чинних та розробка низки спецкурсів 3 широкого спектру проблем екологічного виховання. Таким чином, поєднання теоретичних і практичних 


\section{АКТУАЛЬНІ ПРОБЛЕМИПРОФЕСІЙНОЇ ОСВІТИ У НАУКОВОМУ ПРОСТОРІПРОФЕСОРА ТАНІТИЛЮРІНОӤ}

складових навчання і виховання у їх спрямованості на розвиток екологічної культури молодших школярів допоможе педагогам успішно виконувати свою місію у сучасному освітньому середовищі.

Надзвичайною змістовою наповненістю вирізняється стаття професора Т. Люріної "Підготовка педагогічних працівників до інноваційної діяльності в дошкільній освіті” [5], базована на великій джерельній базі і досвіді сучасних педагогів у галузі дошкільної освіти. Автор уточнює зміст основних понять свого дослідження, зокрема таких, як: інновація, інноваційна діяльність педагога-дошкільника тощо, узагальнює свій практичний досвід щодо створення такого освітнього середовища, яке помітно впливає на позитивну динаміку професійно-творчого розвитку майбутніх педагогів. Практичний досвід у Київському університеті імені Бориса Грінченка дав змогу Т. Люріній провести навчальні семінари "Методологічні основи інноваційної діяльності в дошкільній освіті”, “Педагогічні інновації та досвід їх впровадження”, які охоплювали широке коло питань щодо сучасної початкової освіти. Відзначено, що розробка різних аспектів інноваційної діяльності є однією із визначальних ознак наукової школи професора Т. Люріної.

Низку важливих проблем вищої освіти висвітлює стаття Т. Люріної “Підготовка конкурентоспроможних фахівців у вищому педагогічному навчальному закладі" [3]. В науковій розвідці обгрунтовується необхідність вдосконалення професійної підготовки сучасної генерації педагогів до інноваційної діяльності, що віддзеркалює досвід Київського університету імені Бориса Грінченка. Висловлюється думка, “...гуманізація процесу університетської освіти передбачає його кінцевою ціллю не знання, цілісний розвиток майбутнього фахівця" [3, 200 ].

Висновки і перспективи подальших наукових розвідок. Узагальнюючи вищесказане, можна стверджувати, що в науково-педагогічній діяльності Т. Люріної простежується тенденція щодо знаходження розумного балансу між академічними знаннями і прагматичними вміннями. На цих засадах відбувалося написання наукових досліджень педагогічного циклу, які набули розвивального характеру. Важливою складовою думки професора Т. Люріної стає практична діяльність. Така організація освітнього середовища створює підгрунтя для розвитку педагогічних здібностей і педагогічного мислення майбутніх фахівців.

\section{ЛІТЕРАТУРА}

1. Люріна Т. Виховний потенціал української літератури у викладанні українознавства. Вісник Глухівського державного педагогічного університету. Серія: Педагогічні науки. Випуск 3. Глухів, 2003. с. 133 139.

2. Люріна Т. Організаційно-педагогічні основи адаптивної системи навчання молодших школярів: аспект особистісно орієнтованого підходу. Гуманітарний вісник ДВНЗ “Переяслав-Хмельницький державний педагогічний університет імені Григорія Сковороди": збірник наукових праць. ПереяславХмельницький, 2011. Вип. 21. с. 161-164.

3. Люріна Т. Підготовка конкурентоспроможних фахівців у вищому педагогічному навчальному закладі. Гуманітарний вісник ДВНЗ “Переяслав-Хмельницький державний педагогічний університет імені Григорія Сковороди": збірник наукових праць. ПереяславХмельницький, 2015. Вип. 24. с. 198-203.

4. Люріна Т. Підготовка майбутніх учителів початкової школи до формування в учнів екологічної культури. Вісник Київського національного університету імені Тараса Шевченка, 2016. с.60-62.

5. Люріна Т. Підготовка педагогічних працівників до інноваційної діяльності в дошкільній освіті. Гуманітарний вісник ДВНЗ “Переяслав-Хмельнищький державний педагогічний університет імені Григорія Сковороди": Науково-теоретичний збірник. Переяслав-Хмельницький, 2008. Вип. 14. с.148-150.

\section{REFERENCES}

1. Lurina, T. (2003). Vykhovnyy potentsial ukrayinskoyi literatury u vykladanni ukrayinoznavstva [Educational potential of Ukrainian literature in the teaching of Ukrainian studies]. Issue 3, Hlukhiv, pp. 133-139. [in Ukrainian].

2. Lurina, T. (2011). Orhanizatsiyno-pedahohichni osnovy adaptyvnoyi systemy navchannya molodshykh shkolyariv: aspekt osobystisno oriyentovanoho pidkhodu [Organizational and pedagogical bases of adaptive system of education of junior schoolchildren: aspect of personality-oriented approach]. of the SHEI "Hryhorii Skovoroda university in Pereiaslav". Issue 21. pp. 161-164. [in Ukrainian].

3. Lyurina, T. (2015). Pidhotovka konkurentospromozhnykh fakhivtsiv u vyshchomu pedahohichnomu navchalnomu zakladi [Training of competitive specialists in higher pedagogical educational institution]. of the SHEI "Hryhorii Skovoroda university in Pereiaslav". Issue 24. pp. 198-203. [in Ukrainian].

4. Lurina, T. (2016). Pidhotovka maybutnikh uchyteliv pochatkovoyi shkoly do formuvannya $\mathrm{v}$ uchniv ekolohichnoyi kultury [Preparation of future primary school teachers for the formation of ecological culture in students]. Kyiv, pp.60-62. [in Ukrainian].

5. Lurina, T. (2008). Pidhotovka pedahohichnykh pratsivnykiv do innovatsiynoyi diyalnosti $\mathrm{v}$ doshkilniy osviti [Preparation of teachers for innovation in preschool education]. of the SHEI "Hryhorii Skovoroda university in Pereiaslav". Issue 14. pp.148-150. [in Ukrainian].

Стаття надійшла до редакції 28.05.2020 